\title{
The edge of the Empire: diet characterization of medieval Rome through stable isotope analysis
}

\author{
Sara Varano ${ }^{1}$. Flavio De Angelis ${ }^{1}$. Andrea Battistini ${ }^{2}$ - Luca Brancazi ${ }^{3}$ - Walter Pantano ${ }^{2}$. Paola Ricci ${ }^{4}$. \\ Marco Romboni ${ }^{1}$ - Paola Catalano ${ }^{5}$. Valentina Gazzaniga ${ }^{6}$. Carmine Lubritto ${ }^{4} \cdot$ Riccardo Santangeli Valenzani $^{7}$. \\ Cristina Martínez-Labarga ${ }^{1} \cdot$ Olga Rickards $^{1}$
}

Received: 4 January 2020 / Accepted: 10 July 2020 / Published online: 31 July 2020

(C) The Author(s) 2020

\begin{abstract}
This paper aims to define the dietary profile of the population of early medieval Rome (fifth-eleventh centuries CE) by carbon and nitrogen stable isotope analysis. This period was characterized by deep changes in the city's economic, demographic, and social patterns, probably affecting its inhabitants' nutritional habits. Carbon and nitrogen stable isotope analysis of bone collagen was used to detect the nutritional profile of 110 humans from six communities inhabiting the city center of Rome and one from the ancient city of Gabii. Thirteen faunal remains were also analyzed to define the ecological baseline of the medieval communities. The isotopic results are consistent with a diet mainly based on the exploitation of $\mathrm{C}_{3}$ plant resources and terrestrial fauna, while the consumption of aquatic resources was detected only among the San Pancrazio population. Animal protein intake proved to be similar both among and within the communities, supporting a qualitatively homogenous dietary landscape in medieval Rome. The comparison with isotopic data from the Imperial Age allowed us to detect a diachronic nutritional transition in ancient Rome, in which the collapse of the Empire, and in particular the crisis of economic power and the trade system, represented a tipping point for its population's nutritional habits.
\end{abstract}

Keywords Early Middle Ages · Ancient Rome $\cdot$ Stable isotope analysis $\cdot$ Bone collagen · Diet research

\section{Introduction}

The decline of the Western Roman Empire (476 CE) represented a remarkable tipping point for the history of the ancient world. Archeological and historical sources exhaustively

Electronic supplementary material The online version of this article (https://doi.org/10.1007/s12520-020-01158-3) contains supplementary material, which is available to authorized users.

Sara Varano

saravarano89@gmail.com

$\triangle$ Flavio De Angelis

flavio.de.angelis@uniroma2.it

1 Centre of Molecular Anthropology for Ancient DNA Studies, University of Rome Tor Vergata, Via della Ricerca Scientifica 1, 00133 Rome, Italy

2 Collaborator of Servizio di Antropologia, Soprintendenza Speciale Archeologia, Belle Arti e Paesaggio di Roma, Rome, Italy

3 Scuola di Dottorato in Archeologia Post-Classica, Sapienza Università di Roma, Piazzale Aldo Moro 5, 00185 Rome, Italy depict this period, and the combination of these information and scientific data can clarify as the events that followed the deposition of the Emperor Flavius Romulus Augustus influenced the lifestyles of the Romans (Ward-Perkins 2005; Heather 2006). Especially, the dietary characterization of

4 Dipartimento di Scienze e Tecnologie Ambientali, Biologiche e Farmaceutiche, Università degli Studi della Campania "Luigi Vanvitelli”, Via Vivaldi 43, 81100 Caserta, Italy

5 Former Servizio di Antropologia, Soprintendenza Speciale Archeologia, Belle Arti e Paesaggio di Roma, Rome, Italy

Unità di Storia della Medicina e Bioetica, Dipartimento di Scienze e Biotecnologie medico-chirurgiche, Sapienza Università di Roma, Viale dell'Università 34, 00185 Rome, Italy

7 Dipartimento di Studi Umanistici, Università degli Studi Roma Tre, Via Ostiense 234-236, 00144 Rome, Italy 
people living in the heart of the Western Roman Empire could fill a gap in the current scientific knowledge about the economic and social impact that Empire's decline has had on Roman people.

The transition towards the Early Middle Ages (sixth-ninth centuries $\mathrm{CE}$ ) was marked by a crisis of the centralized economy, and the simultaneous closure of several trade routes resulted in a significant shift to a self-sufficient economic system (Graeber 2011; Pounds 2014). Indeed, the former Imperial system intensively supported agricultural practices, and advanced techniques became widespread throughout the Empire through trade contacts (Hopkins 2009). Both maritime and terrestrial trades increased in the Imperial period (first-third centuries CE); exchanges with faraway areas, such as India and China, provided Imperial Rome with novel foodstuff and goods (McLaughlin 2010), accessible to citizens through markets (horrea) (Holleran 2012). This thriving system suddenly collapsed in the fourth century CE. The Gothic War $(461 \mathrm{CE}-476 \mathrm{CE})$ reduced the population of Rome to approximately 30,000 inhabitants, who relocated, forming small communities close to religious or manufacturing centers (Kulikowski 2008). The political instability triggered a drastic decline in trade while depopulation led to a crisis of the agricultural system (Heather 2006). Then, centralized provisions, such as those granted by the Praefectus annonae, disappeared (Garnsey 1999; Saltini 2010; Graeber 2011). These conditions resulted in a self-sufficient economy where each community produced the resources necessary for its own subsistence (Saltini 2010; Graeber 2011).

Nevertheless, the arrival of foreign people, in particular Germanic invaders, probably introduced novel dietary preferences to the lands of the former Roman Empire, leading to an increase in the consumption of foodstuff untypical in Imperial period (first-third centuries CE) (Hakenbeck et al. 2010; Lightfoot et al. 2012). The introduction of new preferences and lifestyles following people movements represents one of the most significant markers of post-Imperial lifestyles in several European populations (López-Costas and Müldner 2016; Lightfoot et al. 2012).

Literary sources provide us plentiful information about the dietary profile of the early medieval Italian people (Montanari 1979, 1981, 1988, 2012; Nada Patrone 1981; Adamson 2004) that could be compared with the scientific evidence related to their dietary reconstruction. During this period, people from the Italian Peninsula used to base their diet on terrestrial foodstuffs consisting of grains, legumes, fruits, and vegetables, as well as animal proteins from meat and secondary products, such as milk and dairy products (Montanari 1988). A sizeable consumption of marine fish was not widespread and probably restricted to wealthier members of society (Ervynck et al. 2003; Prowse et al. 2004, 2005). This picture of the dietary landscape of the Middle Ages in Italy (fifth-fifteenth centuries CE) is supported by molecular data from paleo diet research (Reitsema and Vercellotti 2012; Ricci et al. 2012; Pescucci et al. 2013; Iacumin et al. 2014; Scorrano et al. 2014; Ciaffi et al. 2015; Torino et al. 2015; Baldoni et al. 2016, 2018, 2019), even though it is far from being fully characterized.

Little information is currently available for the population of Rome, which putatively suffered most from the consequences of the Empire's decline. This study tries to bridge this gap through the molecular analysis of six funerary contexts dating from the fourth to the eleventh centuries CE. This skeletal material represents a promising area of investigation into Roman history during the Middle Ages (fifth-fifteenth centuries $\mathrm{CE}$ ), providing a glimpse into the dietary profile of the Romans beyond the collapse of the Western Roman Empire.

This paper has three main objectives: (i) the dietary characterization of the early medieval Roman population, (ii) the evaluation of the medieval diet in Rome compared with other Italian sites, and (iii) a comparison between medieval and imperial data from Rome in order to identify the impact of the Empire's decline on their dietary habits.

\section{Stable isotopes and diet}

The analysis of the ratios of carbon $\left({ }^{13} \mathrm{C} /{ }^{12} \mathrm{C}\right)$ and nitrogen $\left({ }^{15} \mathrm{~N} /{ }^{14} \mathrm{~N}\right)$ stable isotopes from bone proteins is widely used to investigate dietary patterns in ancient populations (Lelli et al. 2012; Itahashi et al. 2018; Pestle and Laffoon 2018; Scorrano 2018; De Angelis et al. 2019).

These ratios are expressed as parts per mil $(\% o$ ) by the delta notation $(\delta)$, relative to a reference material: atmospheric $\mathrm{N}_{2}$ (ambient inhalable reservoir, AIR) for nitrogen and the Vienna-PeeDee belemnite (VPDB) marine limestone for carbon (Mariotti 1983; Coplen 1996). This isotope signatures provide information about diet: carbon and nitrogen primarily derive from dietary proteins and carbon can also be obtained from carbohydrates and lipids, in particular when the diet is low in protein (De Niro 1985; Ambrose and Norr 1993; Tieszen and Fagre 1993).

The isotopic analysis could be performed on collagen, which represents the leading protein component of bones. This compound is affected by turnover rates in skeletal elements, reflecting the diet for different lifetime stages. Hence, the isotopic analysis for bulk-sampled bones represents a good marker for reconstructing the diet of individuals during the last years of their life. The extent of this period varies depending on the skeletal district that is sampled, but a rough estimation could be set to 10-15 years before death (Hedges et al. 2007).

Mechanisms of carbon isotopic fractionation allow us to determine the consumption of plants with different photosynthetic pathways $\left(\mathrm{C}_{3}\right.$ and $\mathrm{C}_{4}$ plants, with $\mathrm{C}_{4}$ plants depleted in $\left.{ }^{13} \mathrm{C}\right)$ (Tykot 2004). Carbon isotopes also enable us to distinguish between terrestrial-based and marine-based resources in a $\mathrm{C}_{3}$ plantbased environment (Chisholm et al. 1982; Lubell et al. 1994). Freshwater resources (both lacustrine and riverine) could be also identified (Katzenberg 2008). Furthermore, ${ }^{13} \mathrm{C}$ depletes when 
passing from plant tissues to those of animals $(\sim-1 \%$ ) (Tykot 2004). Nitrogen isotopes are best employed in the identification of the food net position of a species, and a nitrogen increase of 3 $5 \%$ being detectable rising up through each trophic level (Katzenberg 2008). Considering a $\delta^{15} \mathrm{~N}$ value of $0-5 \%$ in plants (with maximum values of about $5 \%$ reached by terrestrial nonleguminous plants), a $\delta^{15} \mathrm{~N}$ value of $8-10 \%$ in human bone collagen has been experimentally observed for a diet rich in terrestrial resources (both plants and animals), with higher values (12$22 \%$ ) for a diet rich in aquatic resources (Unkovich et al. 2001).

Furthermore, isotopic ratios can be biased by metabolic and physiological alterations due to starvation and diseases, when mainly $\delta^{15} \mathrm{~N}$ values are influenced by metabolic factors other than diet. Such a confounding factor could be related to the gluconeogenesis, where glucose is produced from endogenous sources such as alanine, pyruvate, and lactate; and the nitrogen source could be represented by own catabolized tissues (Hobson and Clark 1992; Gannes et al. 1997; Katzenberg and Lovell 1999; Mekota et al. 2006; Olsen et al. 2014). This mechanism results in a further enrichment in $\delta^{15} \mathrm{~N}$, leading to a boost in its values (Hobson and Clark 1992; Gannes et al. 1997).

This process could be considered on a par with the breastfeeding effect as described by Fogel et al. (1989) and Fuller et al. (2006), which have demonstrated that breastfeeding infants' tissues are enriched in ${ }^{15} \mathrm{~N}(2-3 \%$ ) relative to maternal values as they are consuming the mothers' tissue. In particular, an increase in $\delta^{15} \mathrm{~N}$ values occurs with the increasing age of the infant, followed by a decline in $\delta^{15} \mathrm{~N}$ during transitional feeding up to weaning ended (Prowse et al. 2008). This complex scenario for infants is made trickier as the rate of bone turnover in growing infants is magnified: indicators of collagen resorption were 13 times higher in children (2-15 years) than adult values, reflecting a greater rate of bone, and collagen turnover (Beardsworth et al. 1990; Herring et al. 1998). An additional challenge is that weaning can compound the effects of malnutrition, infectious disease, and stress on the infants (McElroy and Townsend 1989). Remarkably, death infants are individuals who did not survive, and the exposure to pathogens and other sources of infection could represent some of their causes of death (Prowse et al. 2008). The infant mortality rate was high in the Pre-antibiotics era (Saunders and Barrans 1999; Rawson 2003), and the period from birth to about 3 years was crucial for child health and development (Beaton 1992).

\section{Materials and methods}

\section{Archeological contexts}

Six funerary areas (fourth-eleventh centuries CE) were chosen for studying the dietary habits of early medieval Romans; the osteological preservation status was the criterion determining their selection. These archeological contexts were recently discovered during civil projects in Rome's current city center. The exception is the San Primitivo church cemetery, which is located in the ancient city of Gabii, close to the lake of Castiglione, $20 \mathrm{~km}$ east of Rome (Becker et al. 2009; Mogetta and Becker 2014) (Table 1) (Fig. 1).

Gabii was first urbanized in the early Iron Age (eighth century BCE). It became densely populated during the Republican period (sixth century BCE-first century $\mathrm{CE}$ ), when it established political, social, and economic legacies with Rome (Becker et al. 2009; Mogetta and Becker 2014). Then, the Imperial Age was marked by a drop in population size until the town was progressively abandoned in the early medieval period (sixth-ninth centuries CE) (Becker et al. 2009), when the land was given over to agricultural production (Quilici 1977; Zapelloni Pavia et al. 2017). This study analyzed the medieval burials dated to tenth and eleventh centuries $\mathrm{CE}$ and located in a cemetery close to San Primitivo church.

The other cemeteries are located in Rome's city center; they were dug up only recently, and the archeological information is still under evaluation.

Piazzale Ostiense (fourth and fifth centuries CE) and Amba Aradam (fifth centuries CE) are two small funerary grounds close to the Tiber river. Despite their low sample size, these skeletal samples were included in the paper because they represent some of the first biological evidence from Rome's Late Antiquity (fourth and fifth centuries CE).

San Pancrazio (seventh and eighth centuries CE) contains the remains of a small community buried within a mausoleum, close to the Tiber river.

Celio is a wide urban area discovered during the archeological excavations at Piazza Celimontana. The zone was inhabited from at least the Republican period (sixth century BCE-first century CE), as witnessed by the discovery of the oldest Roman aqueduct (third century BCE). The analyzed skeletal material dates to the medieval period; context dating identified two time frames: the sixth-ninth centuries CE (here called Celio I) and the tenth and eleventh centuries CE (here called Celio II).

Lastly, an archeological context (tenth and eleventh centuries CE) was found near the Foro della Pace, along the road that runs alongside the south side of the Forum.

\section{Analytical methods}

Carbon and nitrogen stable isotope analysis was performed on 110 human bones. Table 1 reports the number of individuals considered for each cemetery. The sample also includes faunal bones from San Pancrazio, Gabii, and the Colosseo to gain information about Rome's ecological background (Table 1). 
Table 1 Number of samples analyzed and funerary context date

\begin{tabular}{llll}
\hline Species & Site & Date & $N$ \\
\hline Homo sapiens & Piazzale Ostiense & fourth and 5th centuries CE & 10 \\
Homo sapiens & Amba Aradam & fifth century CE & 4 \\
Homo sapiens & San Pancrazio & seventh and eighth centuries CE & 9 \\
Homo sapiens & Celio I & sixth-ninth centuries CE & 23 \\
Homo sapiens & Celio II & tenth and eleventh centuries CE & 9 \\
Homo sapiens & Foro della Pace & tenth and eleventh centuries CE & 19 \\
Homo sapiens & Gabii San Primitivo & tenth and eleventh centuries CE & 36 \\
Sus scrofa & San Pancrazio & seventh and eighth centuries CE & 3 \\
Bos taurus & San Pancrazio & seventh and eighth centuries CE & 2 \\
Canis familiaris & San Pancrazio & seventh and eighth centuries CE & 1 \\
Canis familiaris & Gabii San Primitivo & tenth and eleventh centuries CE & 1 \\
Ovis aries & Gabii San Primitivo & tenth and eleventh centuries CE & 1 \\
Gallus gallus & Colosseo I & fifth century CE & 1 \\
Ovis sp. & Colosseo I & fifth century CE & 1 \\
Sus scrofa & Colosseo I & fifth century CE & 1 \\
Capra hircus & Colosseo I & fifth century CE & 1 \\
Sus scrofa & Colosseo II & sixth-ninth centuries CE & 1 \\
\hline
\end{tabular}

Rib fragments (about $1 \mathrm{~g}$ ) were collected from each sample for avoiding the bias of heterogenous collagen turnover. The bone surface was cleaned by a sterile surgical blade, and the sample was pulverized with a drill. The protein fraction was extracted by the modified Longin protocol (Brown et al. 1988). About $0.5 \mathrm{~g}$ of powdered bone was demineralized in $0.6 \mathrm{M} \mathrm{HCl}$ for 2 days at $4{ }^{\circ} \mathrm{C}$. Then the acid was removed by $\mathrm{ddH}_{2} \mathrm{O}$, and the remaining residue was gelatinized with $0.001 \mathrm{M} \mathrm{HCl}$ at $65{ }^{\circ} \mathrm{C}$ for $24 \mathrm{~h}$. The gelatine protein was concentrated using Amicon ${ }^{\circledR}$ Ultra-4 Centrifugal Filter Units with Ultracel $®$ membranes (Millipore) $(30-\mathrm{kDa}$ size). The solute retained in the filter was frozen at $-80{ }^{\circ} \mathrm{C}$ for 4 ho and then freeze-dried for 1 to 2 days. Each extraction run was simultaneously performed on modern bovine bone used as a reference control. For each extract, $0.8-1.2 \mathrm{mg}$ of collagen was weighed, put into tin capsules, and analyzed in duplicate for $\delta^{13} \mathrm{C}$ and $\delta^{15} \mathrm{~N}$ with an elemental analyzer isotope ratio mass spectrometer (EA-IRMS) at the iCONa Laboratory of the University of Campania. Analytical precision was $\pm 0.3 \%$ o for $\delta^{15} \mathrm{~N}$, concerning the AIR, and $\pm 0.1 \%$ for $\delta^{13} \mathrm{C}$ reported with respect to the VPDB standard. Criteria for assessing the quality of preservation were carbon content $(\mathrm{C} \%)$, nitrogen content (N\%), and C/N ratio (De Niro 1985; Ambrose 1993; van Klinken 1999).

\section{Statistical methods}

Past v.3.14 software was used to identify descriptive statistics, run the Mann-Whitney $U$ comparison tests, calculate the coefficients of variation, and perform the analysis of variance
(ANOVA) among medieval communities (v. 3.14; Hammer et al. 2001).

The linear mixing model proposed by Fraser et al. (2013) and also applied by Fontanals-Coll et al. (2017) was used to calculate the theoretical endpoints for aquatic and terrestrial protein consumption in order to evaluate the animal protein intake in the human diet. Unfortunately, no remains of aquatic resources were found in the funerary contexts analyzed in this study. Therefore, the freshwater fish values from the medieval French sites (fifth-eleventh centuries CE) reported in Mion et al. (2019) and the marine fish values available for the imperial site of Velia, Italy (first-second centuries CE) (Craig et al. 2009), were used to build up the model. To the best of our knowledge, these are the best site comparisons based on time frame and topography that could be used to define the "regional" aquatic isotopic features.

Furthermore, the Bayesian mixing model provided by the software FRUITS v3.0 (Food Reconstruction Using Isotopic Transferred Signals) (Fernandes et al. 2014) was elaborated. The model allows for probabilistic quantification of dietary inputs and incorporates food macronutrients, elemental composition, and isotopic composition in its calculation. Average isotopic values of each site were used as human (consumer) data and all calculated values were input into FRUITS with instrumental uncertainties of $0.1 \%$ of for both carbon and nitrogen. Regarding elemental routing, all nitrogen in collagen was set up as deriving from dietary protein, and the carbon composition of bone protein was stipulated to reflect an average $3: 1$ ratio $(74 \pm 4 \%, 26 \%)$ of dietary protein to energy (Fernandes et al. 2012). Four source groups were built: meat, $\mathrm{C}_{3}$ plants, $\mathrm{C}_{4}$ plants, and freshwater fish. Meat isotope values 
Fig. 1 Topographical location of the analyzed communities

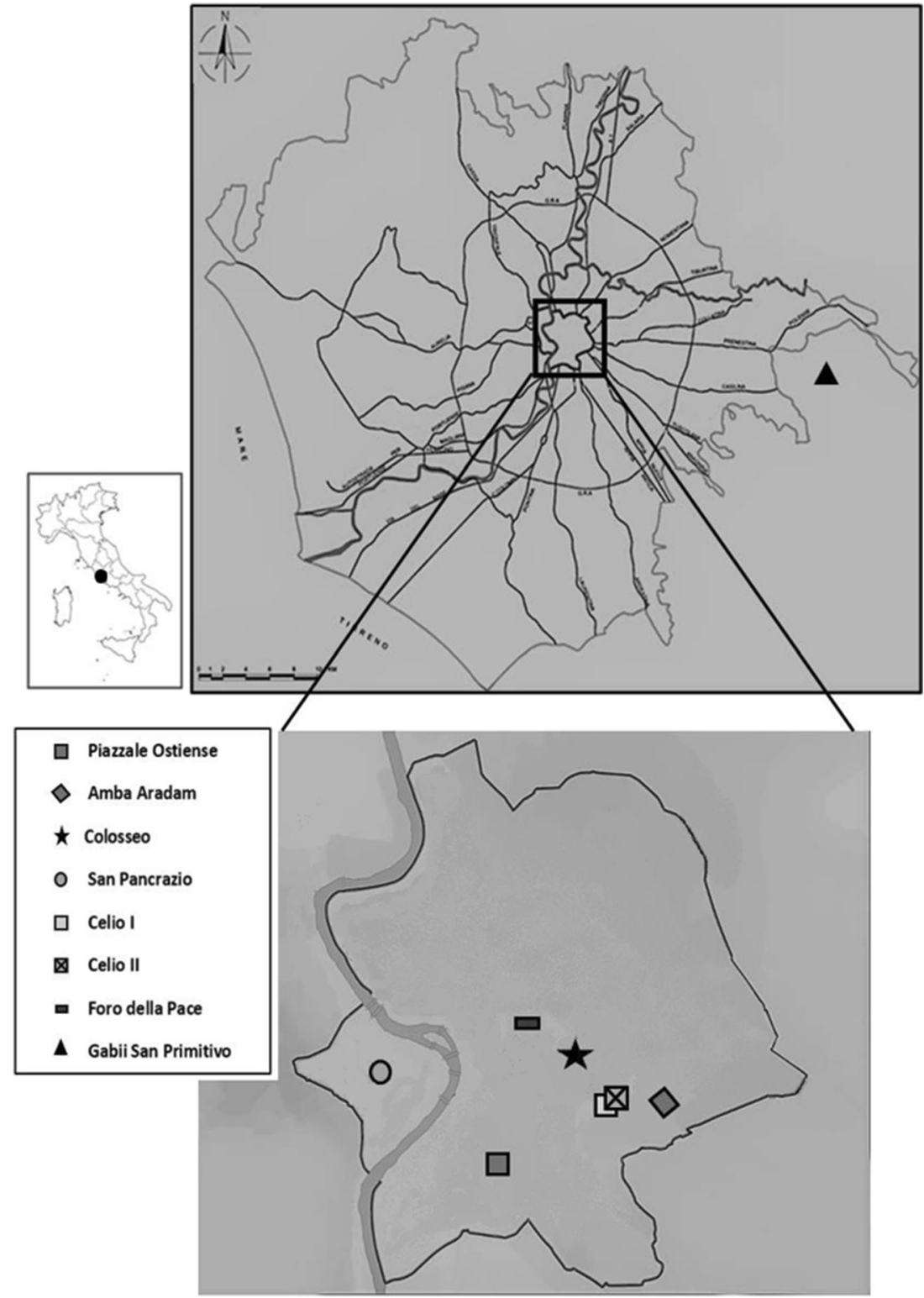

were averaged for the herbivores isotopic values generated in this study. As well as the for the Fraser's linear model, the freshwater fish values from France reported in Mion et al. (2019) were used. Lastly, grain samples from central Italy (GBrescia et al. 2002; Gismondi et al. 2020) and the isotopic data recruited in IsoArcH repository (Salesse et al. 2018) were used for elaborating the model. Macronutrient composition of each food group was established by reference to a range of comparable food in the USDA National Nutrient Database for Standard Reference (Ahuja et al. 2017). Dry weights for each $100 \mathrm{~g}$ of reference food were estimated, and the protein and energy (lipids and carbohydrates) compositions of dried food were calculated and converted to a percentage. Elemental composition of each macronutrient group was based on Morrison et al. (2000). Lastly, isotopic offsets between measured foodstuff isotope values and the isotopic values of specific macronutrients were established according to Tieszen (1991).

R software (ver.3.1.2) (R Core Team 2014) was used for the generation of violin plots to evaluate the distribution of isotopic data.

\section{Results}

\section{Collagen preservation}

Collagen extraction was performed for all the samples, but four did not yield enough collagen for submission to spectrometric analysis (collagen yield $<1 \%$ ). Carbon content higher than or equal to $30 \%$, nitrogen content higher than or equal to $10 \%$ (Ambrose 1993), and atomic $\mathrm{C} / \mathrm{N}$ ratio between 2.9 and 
3.6 (De Niro 1985) were used as a criterion to assess a suitable preservation status. All the faunal and 100 human samples fitted the quality criteria. AA1, AA4, and GSP9 were depleted in $\mathrm{C}$ and/or $\mathrm{N}$ composition, but their atomic $\mathrm{C} / \mathrm{N}$ ratio and the associated isotopic results are consistent with comparable samples. Conversely, PO9, PO10, and FP18 samples showed a $\mathrm{C} / \mathrm{N}$ ratio higher than 3.6 , thus the individual isotope data were excluded.

The analytical data for faunal and human bones, along with collagen quality indicators, are listed in Tables 2 and Supplementary Information Table 1, respectively. For the human samples, information about sex and age at death is also reported in Supplementary Information Table 1.

\section{Isotopic data from fauna}

In order to detect the isotopic composition of faunal sources available as putative foodstuff for past populations, it is necessary to evaluate $\delta^{13} \mathrm{C}$ and $\delta^{15} \mathrm{~N}$ isotope values of domestic and wild faunal remains. Unfortunately, only 13 animal bones are featured in this study. However, faunal remains from various species are available for Medieval Latium (Baldoni et al. 2016, 2018, 2019); they were analyzed in conjunction with this study's values to aid in reconstructing a reliable animal baseline used for the dietary analysis of Rome's medieval population.

The obtained herbivore isotopic values (Bos taurus, Ovis aries, Ovis sp., and Capra hircus from San Pancrazio, Gabii San Primitivo, and Colosseo I; mean $\delta^{13} \mathrm{C}=-20.4 \pm 0.8 \%$ 1 s.d.- and mean $\delta^{15} \mathrm{~N}=4.7 \pm 1.1 \% 0_{-1}$ s.d.-) are similiar to the herbivore's isotopic values available for the sites of Colonna, Allumiere, and Cencelle (Bos taurus, Ovis aries, and Equus asinus; mean $\delta^{13} \mathrm{C}=-20.8 \pm 0.8 \%$ - 1 s.d.- and mean $\delta^{15} \mathrm{~N}=4.7 \pm 0.7 \%$ - 1 s.d.-). Overall, these herbivore isotopic data are consistent with values for a terrestrial $\mathrm{C}_{3^{-}}$based European ecosystem (Schwarcz and Schoeninger 1991); their $\delta^{15} \mathrm{~N}$ values are in keeping with the expected trophic level for the identified species.

The five Sus scrofa from San Pancrazio, Colosseo I, and Colosseo II have similar isotope values (mean $\delta^{13} \mathrm{C}=-20.2$ $\pm 0.5 \%$ - 1 s.d. - and mean $\delta^{15} \mathrm{~N}=5.1 \pm 0.9 \%$ - 1 s.d.- $)$ to the sheep and cattle, suggesting that they consumed an herbivorous diet rather than an omnivorous one. The literature data also show similar isotope values between the Sus domesticus and the herbivores (mean $\delta^{13} \mathrm{C}=-21.1 \pm$ $0.5 \%$ - 1 s.d. - and mean $\delta^{15} \mathrm{~N}=4.9 \pm 1.3 \%$ - 1 s.d.-) (Baldoni et al. 2016, 2018, 2019).

The $\delta^{15} \mathrm{~N}$ values of two domestic dogs (Canis familiaris) from San Pancrazio and Gabii San Primitivo are markedly different $\left(\delta^{15} \mathrm{~N}=11.6 \%\right.$ and $\delta^{15} \mathrm{~N}=8.2 \%$, respectively), despite they are similar to the $\delta^{15} \mathrm{~N}$ values of their communities. Similarly to the Gallus gallus from Colonna $\left(\delta^{15} \mathrm{~N}=7.8 \%\right.$ ) (Baldoni et al. 2016), the chicken analyzed in the current paper points out an enriched $\delta^{15} \mathrm{~N}$ value $(6.1 \%$ ) that could reflect more omnivorous feeding habits.

\section{Isotopic data from humans}

The isotopic values obtained for the humans (Supplementary Information Table 1) are plotted in graph form in Fig. 2. Considering the human sample overall, a certain heterogeneity can be observed both in the $\delta^{13} \mathrm{C}$ and $\delta^{15} \mathrm{~N}$ values. Indeed, the $\delta^{13} \mathrm{C}$ ranges from -17.0 to $-20.9 \%$ (average $\delta^{13} \mathrm{C}$ value $19.1 \% \circ \pm 0.6-1$ s.d.- $)$, while the $\delta^{15} \mathrm{~N}$ values span from 6.4 to $12.7 \%$ (average $\delta^{15} \mathrm{~N}$ value $8.8 \% \circ \pm 1.3-1$ s.d.-). Notably, people from San Pancrazio and two outliers from Gabii San Primitivo are marked by $\delta^{15} \mathrm{~N}$ values higher than $10.4 \%$.
Table 2 Species, collagen quality indicators, and stable isotope values of faunal samples

\begin{tabular}{|c|c|c|c|c|c|c|c|c|}
\hline Site & Sample & Species & $\begin{array}{l}\text { Collagen } \\
\text { yield }(\%)\end{array}$ & $\% \mathrm{C}$ & $\% \mathrm{~N}$ & $\begin{array}{l}\mathrm{C} / \\
\mathrm{N}\end{array}$ & $\begin{array}{l}\delta^{13} \mathrm{C} \\
\% o\end{array}$ & $\begin{array}{l}\delta^{15} \mathrm{~N} \\
\% o\end{array}$ \\
\hline San Pancrazio & SP1 & Sus scrofa & 3.6 & 40.1 & 12.6 & 3.3 & -19.6 & 5.0 \\
\hline San Pancrazio & $\mathrm{SP} 2$ & Sus scrofa & 8.2 & 38.9 & 14.8 & 3.2 & -20.2 & 5.5 \\
\hline San Pancrazio & $\mathrm{SP} 3$ & Sus scrofa & 4.1 & 40.2 & 15.1 & 3.1 & -21.0 & 4.7 \\
\hline San Pancrazio & SP4 & Bos taurus & 3.9 & 41.6 & 13.9 & 3.2 & -19.9 & 4.0 \\
\hline San Pancrazio & SP5 & Bos taurus & 5.2 & 39.9 & 11.4 & 3.3 & -19.6 & 6.4 \\
\hline San Pancrazio & SP6 & Canis familiaris & 3.4 & 38.6 & 15.8 & 3.3 & -19.3 & 11.6 \\
\hline Gabii San Primitivo & GSP1 & Canis familiaris & 6.1 & 38.8 & 13.2 & 3.4 & -19.6 & 8.2 \\
\hline Gabii San Primitivo & GSP2 & Ovis aries & 3.9 & 41.2 & 11.8 & 3.1 & -20.1 & 4.5 \\
\hline Colosseo I & CL1 & Gallus gallus & 5.2 & 50.9 & 18.5 & 3.2 & -19.8 & 6.1 \\
\hline Colosseo I & CL2 & Ovis sp. & 4.3 & 44.4 & 16.5 & 3.1 & -21.4 & 4.9 \\
\hline Colosseo I & CL3 & Sus scrofa & 6.8 & 39.3 & 14.5 & 3.2 & -19.9 & 6.4 \\
\hline Colosseo I & CL4 & Capra hircus & 3.3 & 40 & 14.7 & 3.2 & -21 & 3.5 \\
\hline Colosseo II & COL1 & Sus scrofa & 4.4 & 43.2 & 15.7 & 3.2 & -20.1 & 4 \\
\hline
\end{tabular}


Fig. 2 Plot of $\delta^{13} \mathrm{C}$ and $\delta^{15} \mathrm{~N}$ human and faunal values. The faunal data were grouped in rectangular boxes defined by their range values. The dotted line boxes were estimated from the faunal boxes for accounting the trophic shift in isotope values from prays to consumers (see text for details). F, freshwater fauna; $\mathrm{TH}$, terrestrial herbivores, respectively. $\mathrm{Fc}$, freshwater resource consumers; $\mathrm{THc}$, terrestrial herbivore consumers; SP, San Pancrazio; COL1, Colosseo I; COL2, Colosseo II; GSP, Gabii San Primitivo

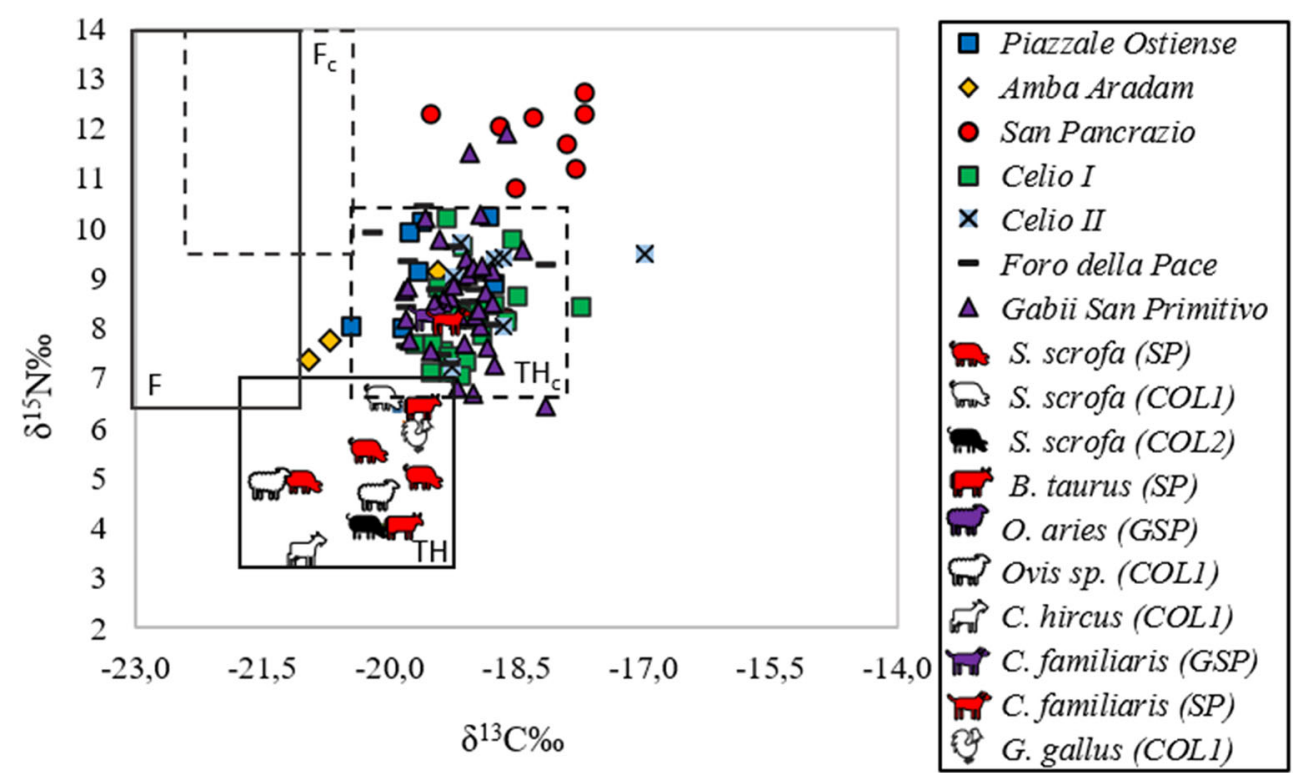

At the best of our knowledge, a careful selection of the samples was made to avoid sampling individuals or bone areas suggestive for the presence of alterations that could influence the isotopic composition of the bone tissue. Likewise, the age at death estimation of children put them outside the breastfeeding period, suggesting that their isotopic values could reliably reflect their complete weaning. The comparison between women values and children data could account for this issue at the community level. Even though we cannot be sure of the parental relationship in child/woman pair, no differences were found between the values of the infants $(0-6$ years at death) $(n=17)$ and women $(n=31)$ in the whole dataset $\left(\delta^{13} \mathrm{C}\right.$, Mann-Whitney $U=209.5, z=-1.6, p$ value $=0.25 ; \delta^{15} \mathrm{~N}$, Mann-Whitney $U=223.5, z=-0.85, p$ value $=0.39)$. Furthermore, no differences have been found between the values of children ( 0 12 years at death) and adults/males and females at each site (coupled Mann-Whitney $U$ tests, Supplementary Information Table 2, and Supplementary Information Table 3). These evidence leads us to consider children data suitable for a community-based dietary reconstruction Accordingly, mean $\delta^{13} \mathrm{C}$ and $\delta^{15} \mathrm{~N}$ values of all the humans at the seven sites have been used for the dietary reconstruction (Table 3 ).

The human dietary reconstruction was firstly carried out following the linear model proposed by Fraser et al. (2013) and Fontanals-Coll et al. (2017). The faunal average values $\left(\delta^{13} \mathrm{C}=-20.2 \% \circ \pm 0.6-1\right.$ s.d. - and $\delta^{15} \mathrm{~N}=5.0 \%$ $\pm 1.0-$ 1 s.d.-) were used to envisage the local baseline of the trophic food chain. From the mean $\delta^{13} \mathrm{C}$ value of terrestrial fauna, a theoretical terrestrial endpoint of about $-19.2 \%$ ( -20.2 adjusted to $+1 \%$ o for fractionation processes due to preypredator relationship) was estimated. In the same way, a theoretical freshwater endpoint of about $-21.8 \%$ (Mion et al. 2019) and a theoretical marine endpoint of about $-13.1 \%$ (Craig et al. 2009) were estimated. The theoretical threshold for terrestrial animal protein consumption was calculated, adjusting for $4 \%$ o the average faunal $\delta^{15} \mathrm{~N}$ value $(5.0 \%$ ). The $3-5 \%$ range is used as an average range to account for the trophic shift, even though the magnitude of the trophic level effect may be higher than $5 \%$, as explained by O'Connell et al. 2012, and 4\%o represents the midpoint of this range. All the above procedures resulted in a range of $8.0-10.0 \%$ o for terrestrial faunal protein consumption in humans. Similarly, a theoretical freshwater endpoint of about 12.5$14.5 \%$ (Mion et al. 2019) and a theoretical marine threshold of about 12-14\%o (Craig et al. 2009) were established.

Therefore, in reference to Fig. 2, almost all the individuals are placed within the box corresponding to terrestrial animal consumers. The isotopic values are consistent with a diet mainly based on the consumption of $\mathrm{C}_{3}$ plant resources and terrestrial fauna, with almost all the humans occupying a trophic level higher than herbivores, supporting the hypothesis that terrestrial fauna represents a considerable fraction of the edible resources. To date, the results do not indicate adequate evidence for fish consumption, both marine and freshwater. San Pancrazio is an odd case (seven humans fall outside terrestrial herbivore consumers, Fig. 2). There are two most likely hypotheses, as follows. First, the terrestrial fauna found at San Pancrazio was not consumed by that humans, which burials within a mausoleum qualifying them as a wealthy elite. Secondly, the high $\delta^{15} \mathrm{~N}$ values could be related to an occasional exploitation of freshwater resources. Even though the model displayed in Fig. 2 seems to be in contrast with the latter hypothesis, the unavailability of local data about fish could be misleading as far as this model is concerned. The isotopic values of the French freshwater fish used in the model (Mion et al. 2019), though representing the best references in terms of time frame, could differ from those of the freshwater stocks of the nearby Tiber river. 
Table 3 Mean and standard deviation (SD) for the $\delta^{13} \mathrm{C}$ and $\delta^{15} \mathrm{~N}$ values of each site. Median and 25/75 percentile are also reported

\begin{tabular}{|c|c|c|c|c|c|c|c|c|c|c|c|}
\hline & \multirow[b]{2}{*}{$n$} & \multicolumn{5}{|c|}{$\delta^{13} \mathrm{C}(\%)$} & \multicolumn{5}{|c|}{$\delta^{15} \mathrm{~N}(\% \circ)$} \\
\hline & & Mean & SD & Median & 25 percentile & 75 percentile & Mean & SD & Median & 25 percentile & 75 percentile \\
\hline Piazzale Ostiense & 8 & -19.4 & 0.5 & -19.3 & -19.7 & -18.9 & 8.6 & 0.9 & 8.6 & 8 & 9.1 \\
\hline Amba Aradam & 4 & -20.1 & 0.8 & -20 & -20.8 & -19.3 & 8.2 & 0.8 & 8.1 & 7.4 & 8.9 \\
\hline San Pancrazio & 9 & -18.3 & 0.6 & -18.3 & -18.6 & -17.7 & 11.5 & 1.4 & 12 & 11 & 12.3 \\
\hline Celio I & 22 & -19.0 & 0.4 & -19.1 & -19.3 & -18.9 & 8.2 & 0.9 & 8.1 & 7.4 & 8.5 \\
\hline Celio II & 8 & -18.7 & 0.8 & -19 & -19.2 & -18.7 & 8.8 & 0.9 & 9.2 & 8.1 & 9.5 \\
\hline Foro della Pace & 18 & -19.2 & 0.5 & -19.2 & -19.5 & -19 & 8.8 & 0.8 & 8.8 & 8.2 & 9.3 \\
\hline Gabii San Primitivo & 32 & -19.1 & 0.4 & -19.1 & -19.4 & -18.9 & 8.6 & 1.2 & 8.5 & 7.8 & 9.2 \\
\hline
\end{tabular}

Such a dietary depiction was further supported by the Bayesian model elaborated by FRUITS software (Fernandes et al. 2014), confirming Medieval Roman's diet was based on the exploitation of terrestrial resources (Supplementary Information Fig. 1). Remarkably, terrestrial fauna showed a contribution ranging from 30 to $50 \%$, with the highest level reached by Celio II (Supplementary Information Fig. 1a). Otherwise, $\mathrm{C}_{3}$ plant resources provided a greater contribution of about $50-60 \%$ in all the Roman sites but San Pancrazio (Supplementary Information Fig. 1b). San Pancrazio confirms to be an odd case exhibiting a contribution of fish of about $20 \%$, corroborating the hypothesis of an occasional exploitation of aquatic resources (Supplementary Information Fig. 1c).

The demographic dissection of the whole human sample showed no significant difference between males $(n=45)$ and females $(n=31)$ in either $\delta^{13} \mathrm{C}$ (Mann-Whitney $U$ test, $U / z$ score $=696 /-0.01, p$ value $=0.99)$ or $\delta^{15} \mathrm{~N}$ (Mann-Whitney $U$ test, $U / z$ score $=684.5 /-0.13, p$ value $=0.89)$ values, suggesting no dietary differences between the sexes on an isotopic level (Supplementary Information Fig. 2). Comparison across the different age groups (adults, $n=80$, and children, $n=22$ ) was performed. Also in this case, none statistical differences were found in either $\delta^{13} \mathrm{C}$ (Mann-Whitney $U$ test, $U / z$ score $=733 /-1.19, p$ value $=0.23)$ and $\delta^{15} \mathrm{~N}$ (Mann-Whitney $U$ test, $U / z$ score $=815.5 /-0.52, p$ value $=0.6)$ values (Supplementary Information Fig. 3).

\section{Discussion}

\section{Diet in medieval Rome: a literary perspective}

Our current knowledge about diets in the medieval city of Rome is mainly provided by literary sources (Montanari 1988, 2012; Pearson 1997; Adamson 2004) and archaeozoological evidence, such as the report about the faunal remains from Crypta Balbi and S. Cecilia, Rome (Minniti 2000). Grains and grain-derived products (bread, beer, and gruel) were the primary foodstuffs for poor medieval communities, which farmed a variety of grains (Triticum dicoccum, Triticum spelta, and Triticum aestivum) (Montanari 1988). Even though wheat was the grain preferred, it was highly susceptible to climate variations and watering (Astill and Lobb 1991); this explains why the dietary role of barley (Hordeum vulgare) increased, due to its tolerance for damp and cool weather (Pearson 1997).

Meat was the most prominent component of diet only in communities devoted to pastoralism (Hoffmann 2015). Archeological records suggest that most European medieval communities employed four domestic animals as sources of animal proteins: cattle (Bos taurus), pigs (Sus scrofa), sheep (Ovis aries), and goats (Capra hircus) (Pearson 1997).Similarly, the remains of these species have also been found in Rome, representing in all probability a major food source (Facchin et al. 2018).

The steady consumption of fish was probably restricted to wealthier members of society (Ervynck et al. 2003; Prowse et al. 2004, 2005). Indeed, its trade required highly developed transport systems (Van Neer and Ervynck 2004), which collapsed with the fall of the Roman Empire (McCormick 2001). Only the communities living near lakes, rivers, and seashores could benefit from the availability of fish species (Pearson 1997).

\section{Diet in medieval Rome: an isotopic perspective}

To date, the only available isotopic data for the Early Middle Ages (sixth-ninth centuries CE) pertain to Piazza Madonna di Loreto (eighth century CE), where an omnivorous diet based on the exploitation of terrestrial fauna was described (Pescucci et al. 2013). The individuals analyzed in this survey mainly consumed a terrestrial-based diet, in accordance with the historical period of early medieval communities in the Mediterranean area, where an overall diet marked by plant-derived foods and animal proteins from meat and dairy products was broadly shared (Montanari 1988; Salamon et al. 2008). 
Furthermore, teeth and mandibles from 36 individuals were collected from a mass grave of contemporaries of Leonardo da Vinci at the Palazzo della Cancelleria (about $1480 \mathrm{CE}$ ). A significant contribution of marine fish was detected (Salamon et al. 2008).

\section{Diet in medieval Rome: new isotopic data}

The seven communities herein analyzed seem to have shared a common diet, where meat and $\mathrm{C}_{3}$ plant resources had a dominant role. Otherwise, $\mathrm{C}_{4}$ plant seems not to have been a staple for Rome's inhabitants and notable is the lack of clear evidence for fish consumption in Roman people. Nevertheless, some differences among Roman people can be noted (Fig. 3 and Supplementary Information Table 4). San Pancrazio is different from the other medieval sites, both for $\delta^{13} \mathrm{C}$ and $\delta^{15} \mathrm{~N}$ values (Supplementary Information Table 4). As previously mentioned, the consumption of freshwater resources is there conceivable, but the lack of isotopic data from local freshwater fauna represents a bias for a proper dietary reconstruction. The other sites are homogenous for the $\delta^{15} \mathrm{~N}$ values (Supplementary Information Table 4), underlining the fact that Medieval Roman communities had a similar protein exploitation in diets. However, the differences found for the $\delta^{13} \mathrm{C}$ values (Supplementary Information Table 4) could suggest that each community probably employed different resources as pivotal foodstuffs. They could have farmed different grains, or they could have eaten terrestrial fauna that ate various $\mathrm{C}_{3}$ plant resources. The highly heterogenous farming practices of Early Middle Age communities could account for such variations (Pearson 1997), even though this outcome could be also due to the restricted sample size for some communities. Indeed, wheat was the most cultivated grain because its gluten properties made it the best grain for baking bread.
However, it is more demanding in its cultivation requirements than other grains; moreover, in a bed year, a community growing wheat could risk of losing the entire harvest. Therefore, each community could prefer to cultivate a multitude of grains that allowed for a more efficient use of the fields (Hoffmann 1975). This diversity in the use of different grains could be related to some degree to the period. Indeed, the dates of the communities range from the fourth to the eleventh centuries CE. This wide time frame could be split into three sections (Augenti 2016): Late Antiquity (fourth and fifth centuries CE) (Amba Aradam and Piazzale Ostiense), the Early Middle Ages (sixth-ninth centuries CE) (San Pancrazio and Celio I), and the late phase of the Early Middle Ages (tenth and eleventh centuries CE) (Celio II, Foro della Pace, and Gabii San Primitivo). The ANOVA performed for these three groups confirms that the statistical differences in $\delta^{13} \mathrm{C}$ values are broadly related to their different time frames $\left(\delta^{13} \mathrm{C}: F=\right.$ 3.093, $p=0.0489$ ), suggesting that $C_{3}$ plant resources with different isotopic signatures were cultivated in the Rome area from the fourth to the eleventh centuries $\mathrm{CE}$. This assumption is supported by historical reports that deal with the changes in grain cultivation in Italy during the Early Middle Ages (sixthninth centuries $\mathrm{CE}$ ). Wheat assumed a leading role in the central phase of the Early Middle Ages, along with rye in Northern Italy and barley in Central and Southern Italy (Cortonesi et al. 2002). Starting in the eighth century CE, the cultivation of olive trees spreads throughout Italy (Cortonesi et al. 2002).

ANOVA revealed no differences in $\delta^{15} \mathrm{~N}$ values among the three time frames $\left(\delta^{15} \mathrm{~N}: F=1.033, p=0.3591\right)$, confirming that diets in medieval Rome were characterized by a comparable intake of animal protein over the centuries. These data run opposite to primary sources, describing a decline of the self-sufficient economic system from the tenth century due to
Fig. 3 Plot of human $\delta^{13} \mathrm{C}$ and $\delta^{15} \mathrm{~N}$ mean values of each community. The error bars refer to standard deviations

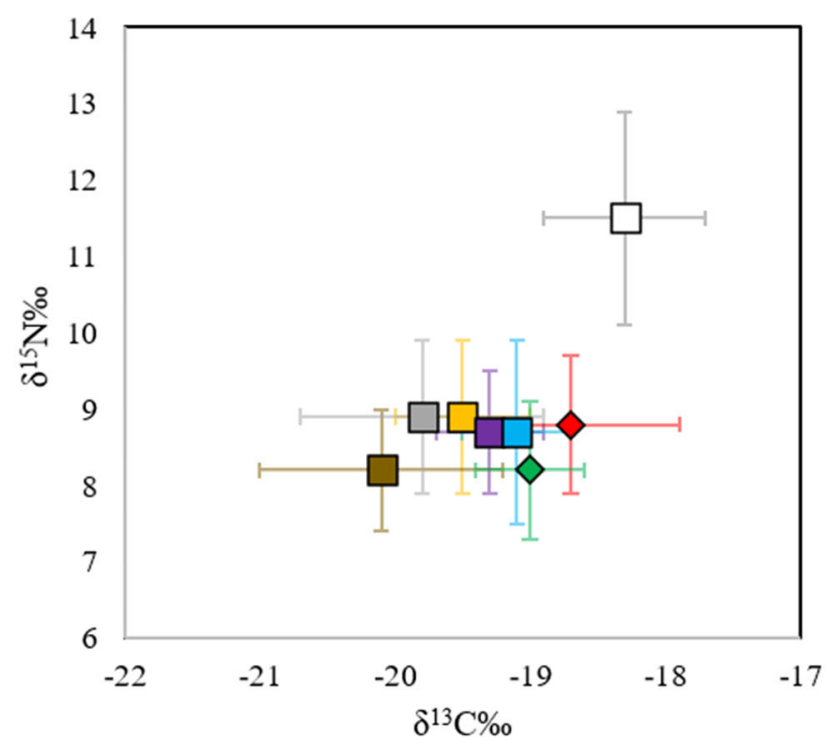

口Piazzale Ostiense

$\square$ Amba Aradam

$\square$ San Pancrazio

$\square$ Foro della Pace

口Piazza Madonna di Loreto

$\square$ Gabii San Primitivo

$\diamond$ Celio II

$\diamond$ Celio I 
Fig. 4 Plot of human $\delta^{13} \mathrm{C}$ and $\delta^{15} \mathrm{~N}$ mean values of medieval Rome and other medieval Italian sites. The error bars refer to standard deviations. N, Northern Italy; C, Central Italy; S, Southern Italy. References are reported in Supplementary Information Table 5

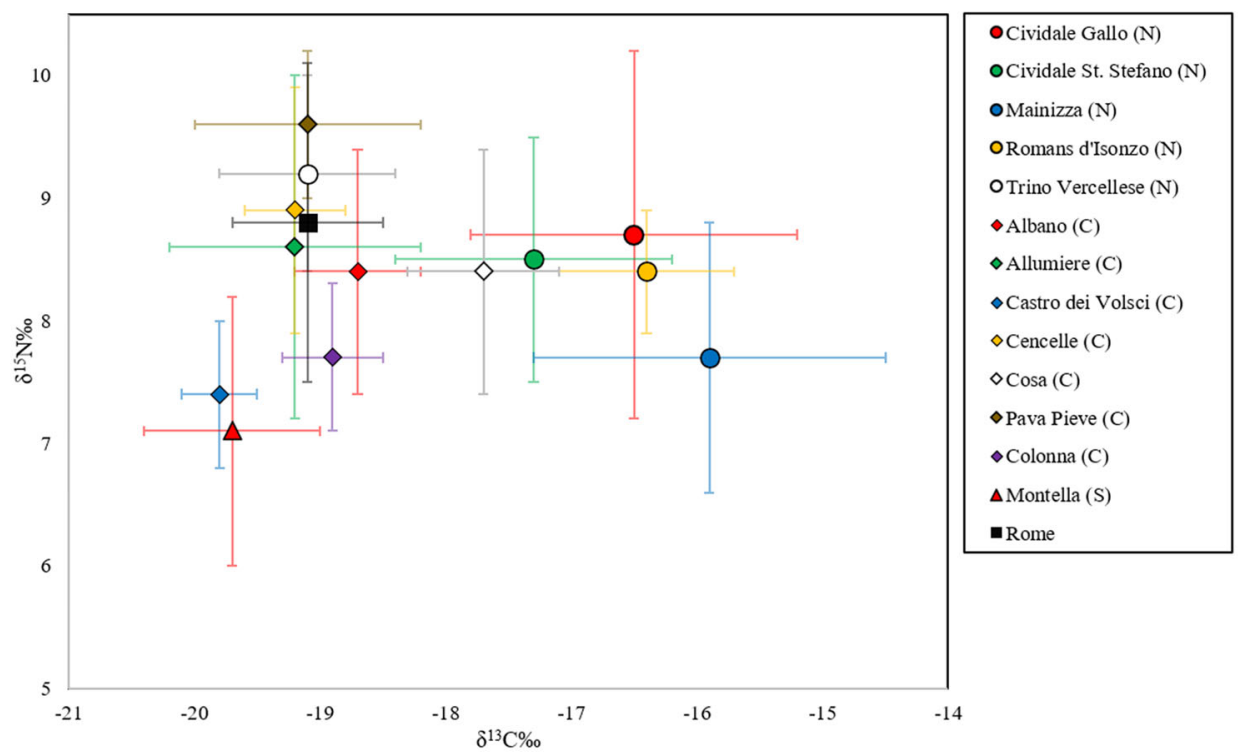

the contemporaneous resurgence of the trading system and the urban economy (Cortonesi et al. 2002).

Remarkable is the dietary overlap between Gabii San Primitivo and the coeval communities Rome's city center, San Pancrazio, being the exception (Supplementary Information Table 4). Gabii was gradually abandoned starting in the Late Antiquity (fourth and fifth centuries CE) and the available area was used for agriculture (Zapelloni Pavia et al. 2017). Meanwhile, Rome lost its leading role as an administrative center and was gradually abandoned (Delogu 2000). In the fifth century CE, Rome was Christianized, the apostolic basilicas were built, and temples and civic monuments were converted into churches. Buildings that were not converted were abandoned. At the same time, the city was gradually depopulated, and the survivors were concentrated in small neighborhoods close to the apostolic basilicas. Consequently, large swathes of the urban area were left uninhabited, becoming either ruins, or uncultivated areas, or a mixture of both (Delogu 2000; Graeber 2011). Therefore, the previous urban landscape became rural (Santangel Valenzani 2011): this could account for the ecological and dietary similarities between people living in Rome and Gabii.

\section{Dietary habits in medieval Italy}

In order to frame the medieval diet in Rome within the coeval Italian context, the data from Rome were merged to consider Rome as a single geographical unit, and then it was compared
Table 4 Coupled Mann-Whitney test between medieval Rome and medieval Italian sites for $\delta^{13} \mathrm{C}$ and $\delta^{15} \mathrm{~N}$ values. Significant $p$ values are reported in italic

\begin{tabular}{|c|c|c|c|c|}
\hline \multirow[t]{2}{*}{ Sites } & \multicolumn{2}{|l|}{$\delta^{13} \mathrm{C}$} & \multicolumn{2}{|l|}{$\delta^{15} \mathrm{~N}$} \\
\hline & $U / Z$ score & $p$ value & $U / Z$ score & $p$ value \\
\hline Rome/Castro dei Volsci & $160.5 /-4.76$ & $1.93 \times 10^{-6}$ & $226 /-4.22$ & $2.48 \times 10^{-5}$ \\
\hline Rome/Albano & $718.5 /-3.33$ & 0.0009 & $1072.5 /-1.19$ & 0.23 \\
\hline Rome/Pava Pieve & $988 /-0.13$ & 0.90 & $657.5 /-2.40$ & 0.016 \\
\hline Rome/Cosa & $168.5 /-7.71$ & $1.21 \times 10^{-14}$ & $1533.5 /-0.82$ & 0.41 \\
\hline Rome/Montella & $1205.5 /-5.23$ & $1.68 \times 10^{-7}$ & $686.5 /-7.25$ & $4.27 \times 10^{-13}$ \\
\hline Rome/Trino Vercellese & $1436 /-0.26$ & 0.79 & $1065 /-2.29$ & 0.02 \\
\hline Rome/Romans d'Isonzo & $14.5 /-9.72$ & $2.3 \times 10^{-22}$ & $2110.5 /-1.31$ & 0.19 \\
\hline Rome/Cividale St. Stefano & $43.5 /-5.04$ & $4.56 \times 10^{-7}$ & $50.5 /-0.72$ & 0.47 \\
\hline Rome/Cividale Gallo & $9.5 /-4.31$ & $1.64 \times 10^{-5}$ & $337 /-0.4$ & 0.69 \\
\hline Rome/Mainizza & $88 /-5.77$ & $7.86 \times 10^{-9}$ & $431.5 /-3.16$ & 0.002 \\
\hline Rome/Colonna & $2204 /-2.69$ & 0.007 & $1269 /-5.98$ & $2.16 \times 10^{-9}$ \\
\hline Rome/Cencelle & $3403 /-1.79$ & 0.07 & $3376.5 /-1.86$ & 0.06 \\
\hline Rome/Allumiere & $2614.5 /-1.74$ & 0.08 & $3023.5 /-0.35$ & 0.73 \\
\hline
\end{tabular}


with isotopic data available for Italy (Supplementary Information Table 5). Figures 4 displays the plotting of human $\delta^{13} \mathrm{C}$ and $\delta^{15} \mathrm{~N}$ mean values of Rome and Italian sites.

The isotopic data were compared using the coupled MannWhitney $U$ test for $\delta^{13} \mathrm{C}$ and $\delta^{15} \mathrm{~N}$ values (Table 4).

Significant differences in $\delta^{13} \mathrm{C}$ values were found between Rome and almost all the other Italian sites (but Pava Pieve, Cencelle, and Allumiere; Ricci et al. 2012; Baldoni et al. 2018 , 2019). Conversely, differences in $\delta^{15} \mathrm{~N}$ were only found between Rome and Castro dei Volsci, Pava Pieve, Montella, Mainizza, and Colonna (Salamon et al. 2008; Ricci et al. 2012; Torino et al. 2015; Iacumin et al. 2014; Baldoni et al. 2016). Thus, the overall alimentary landscape in Italy during the Middle Ages was characterized by a diet founded on a low animal protein intake, especially from aquatic ecosystems (both freshwater and marine ones). This seems to be true also in communities located close to wetlands, such as in Montella (Avellino, Southern Italy), where a creek is located less than $100 \mathrm{~m}$ from the convent where the burials were discovered (Torino et al. 2015). Remarkably, isotopic measurements in Avellino showed a mixed agricultural and pastoral diet and none of the individuals were eating marine protein (Torino et al. 2015). A slight ${ }^{13} \mathrm{C}$ enrichment was found in Friuli Venezia Giulia (North-eastern Italy), putatively linked to the consumption of $\mathrm{C}_{4}$ plants (Castelletti and Mottella De Carlo 2008; Iacumin et al. 2014), possibly introduced by foreign armies (Iacumin et al. 2014). Indeed, $\mathrm{C}_{4}$ plant consumption is also reported in Trino Vercellese (Piemonte, North-western Italy), where the presence of $\mathrm{C}_{4}$ grains such as millet (including Panicum miliaceum and Panicum italicum) and sorghum during the medieval period is well documented (Reitsema and Vercellotti 2012). Conversely, a lack of $\mathrm{C}_{4}$ plant consumption is reported for Rome and Central and Southern Italy (Pava Pieve, Castro dei Volsci, Albano, Colonna, Cencelle, Allumiere, and Montella; Salamon et al. 2008; Ricci et al. 2012; Ciaffi et al. 2015; Torino et al. 2015; Baldoni et al. 2016, 2018), in contrast with the more variegated landscape of Tuscany, for example (Buonincontri et al. 2017). The main cultivations in the Tuscan sites reported by Buonincontri et al. (2017) are naked wheats, barley, and horse bean. This diversity proves the technological abilities reached by Tuscan people during the Middle Ages. Then, between the fourth and the eleventh centuries $\mathrm{CE}, \mathrm{C}_{4}$ plants had a leading role in the Tuscan diet, when the wheat production was gathered by the landlords and then by the cities for their own requirement (Buonincontri et al. 2017).

Significant variation could be noted between early medieval Rome and Italian sites dated to the Late Middle Ages, such as Cosa, Albano, Montella, and Mainizza (Iacumin et al. 2014; Scorrano et al. 2014; Ciaffi et al. 2015; Torino et al. 2015). This stands to reason because of the significant changes of the late medieval period (tenth-fifteenth centuries CE), when the urban sites of Italy and northern Europe started to develop market economies (Lanconelli 1990; Spufford 2003), leading, in turn, to differential consumption of meat and fish (Zug Tucci 1985; Dyer 1993; Clavel 2001). In particular, a clear signal of marine resources consumption was detected by Salamon et al. (2008) in the Late Medieval community from Palazzo della Cancelleria in the Campus Martius in Rome (dated to $1480 \mathrm{ca}$.) (Salamon et al. 2008).

\section{Dietary transition from imperial to medieval period in ancient Rome}

The medieval diet in Europe resulted from significant changes following the collapse of the Roman Empire (476 CE); indeed, deep dietary differences were observed between imperial and post-imperial Mediterranean areas (Fuller et al. 2010; Lightfoot et al. 2012; López-Costas and Müldner 2016). The diachronic survey published by Lightfoot et al. (2012) indicated a dietary change occurring in Balkan region between the Roman Empire's fall and the emergence of the starohrvatski, the early Croatian material culture. Marine resources were abandoned almost completely, and the diet was modified with higher intakes of millet, whose cultivation was favored by a change from a warmer climate to a colder one in the Ionian Sea area (Castagnoli et al. 2002; McDermott et al. 2005). Changes in food exploitation were also detected in Late Antiquity/early medieval Spain. The arrival of new human groups, such as the Sueves, along with modified climatic conditions, led to new dietary preferences related to the exploitation of $\mathrm{C}_{4}$ plants and/or marine resources (Fuller et al. 2010; López-Costas and Müldner 2016), albeit $C_{3}$ plants remained the most exploited foodstuffs (García-Collado et al. 2019).

Similarly, the data of this study were compared with the data available for the cities of Rome and Gabii during the Imperial Age (first-fourth centuries CE) (Killgrove and Tykot 2013; Killgrove and Tykot 2017). Faunal isotopic data are unavailable from these studies. However, they are available from Isola Sacra, on the Tyrrhenian coast (Prowse et al. 2004). These are similar to the medieval faunal values we considered (the average $\delta^{13} \mathrm{C}$ and $\delta^{15} \mathrm{~N}$ values for the herbivores at Isola Sacra are $-20.6 \%$ - 1 s.d. - and 5.3\%o1 s.d.—, respectively; Prowse et al. 2004), suggesting the ecological baseline did not significantly change after the Roman Empire's collapse. The plotting of $\delta^{13} \mathrm{C}$ and $\delta^{15} \mathrm{~N}$ mean values of the diachronic communities from Rome reveals they can be gathered in two clusters, one encompassing the medieval communities, the other encompassing the imperial ones, with San Pancrazio being located in an isolated position (Fig. 5). This assumption is supported by the MannWhitney $U$ test performed between imperial $(n=62)$ and medieval people $(n=106)\left(\delta^{13} \mathrm{C}: U / z\right.$ score $=1632.5 /-5.43, p$ value $=5.47 \times 10^{-8} ; \delta^{15} \mathrm{~N}: U / z$ score $=1515 /-5.83, p$ value $=$ $5.54 \times 10^{-9}$ ); the test highlights the fact that a significant depletion in ${ }^{13} \mathrm{C}$ and ${ }^{15} \mathrm{~N}$ marked the shift from the Imperial Age 
Fig. 5 Plot of $\delta^{13} \mathrm{C}$ and $\delta^{15} \mathrm{~N}$ mean values of imperial and postimperial communities from Rome. The error bars refer to standard deviations

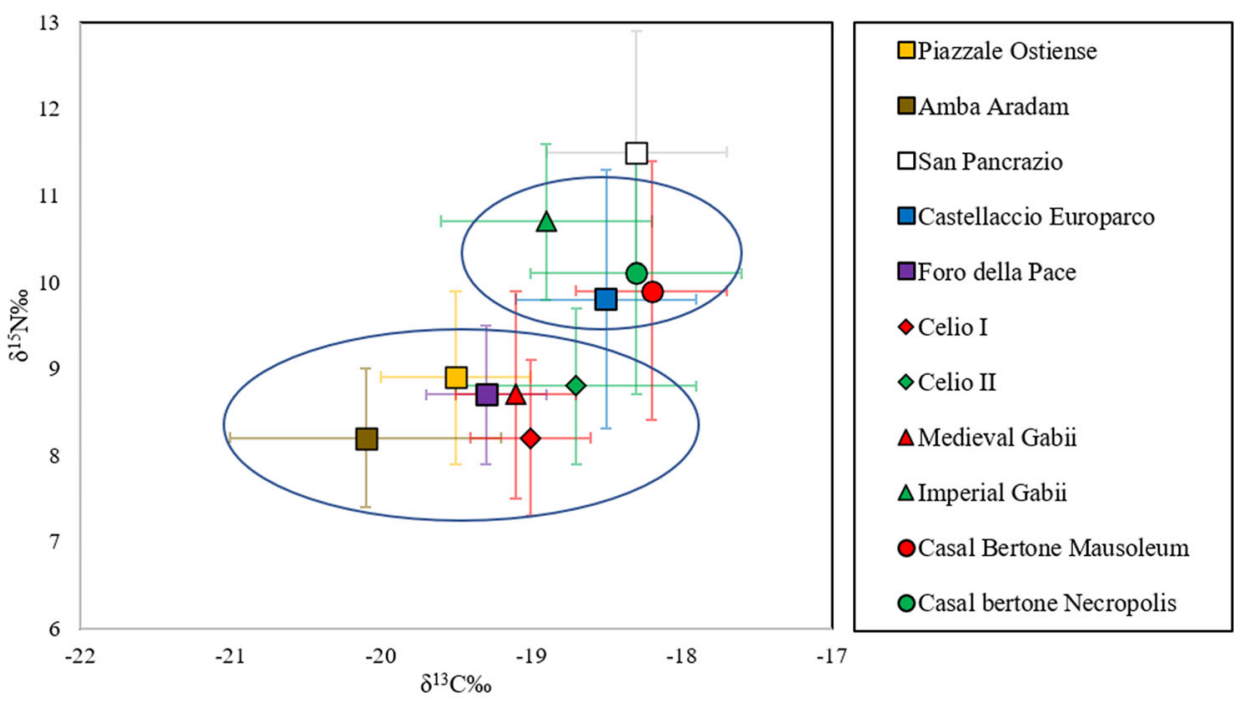

(first-fourth centuries CE) to the Early Middle Ages (sixthninth centuries $\mathrm{CE}$ ) in ancient Rome.

Imperial Romans consumed a diet mainly based on $\mathrm{C}_{3}$ plants and herbivore consumption, with some contribution from aquatic protein (both marine and freshwater) and/or $\mathrm{C}_{4}$ plants.

The drop in the consumption of high-protein resources in the Early Middle Ages (sixth-ninth centuries CE) is also identifiable in Gabii (the average $\delta^{15} \mathrm{~N}$ values in Imperial and Medieval Gabine people are $10.7 \%$ and $8.7 \%$, respectively). The finding of fish hooks in the settlement could suggest using aquatic resources, which is supported by Gabii's location near a volcanic lake (Lake of Castiglione) and its aquifer (Killgrove and Tykot 2017). The progressive city's abandonment probably marked a tipping point for the dietary preferences of Gabii's population, with $\mathrm{C}_{3}$ plant resources seeming to be the leading foodstuff for the medieval population. Overall, the observed drop in the consumption of high trophic level protein resources in the Early Middle Ages (sixth-ninth centuries $\mathrm{CE}$ ) could reflect the deterioration of socio-economic conditions in medieval Rome and its suburbs. Indeed, starvation and disease rapidly spread throughout the area because of the Germanic invasions, as witnessed by the drop in the population of Rome to approximately 30,000 inhabitants (Kulikowski 2008).

Moreover, a wider range of dietary variability could be observed in imperial sites than in the medieval ones. Supplementary Information Table 6 reports the coefficients of variation calculated for $\delta^{13} \mathrm{C}$ and $\delta^{15} \mathrm{~N}$ values of each community. Imperial and medieval communities show comparable coefficients of variation for $\delta^{13} \mathrm{C}$ values, ranging from 2.05 in Medieval Gabii to -4.31 in Amba Aradam, with the extreme value of -11.63 reported for Castellaccio Europarco (Supplementary Information Table 6). This weirdly high value could be explained, however, by the presence of a single outlier in the isotope distribution of people from Castellaccio Europarco (Killgrove and Tykot 2013). The coefficients of variation listed for $\delta^{15} \mathrm{~N}$ values are higher in the imperial Roman communities than in the medieval ones (coefficients of variation in Imperial and Medieval Roman sites range from 14.99 to 15.58 and from 9.46 to 11.91 , respectively), with the opposite trend shown by Gabii (8.24 in Imperial Gabii and 13.73 in Medieval Gabii).

Thus, the wider range of variability in Imperial Rome's $\delta^{15} \mathrm{~N}$ values (Fig. 6) indicates that the isotopic values are more

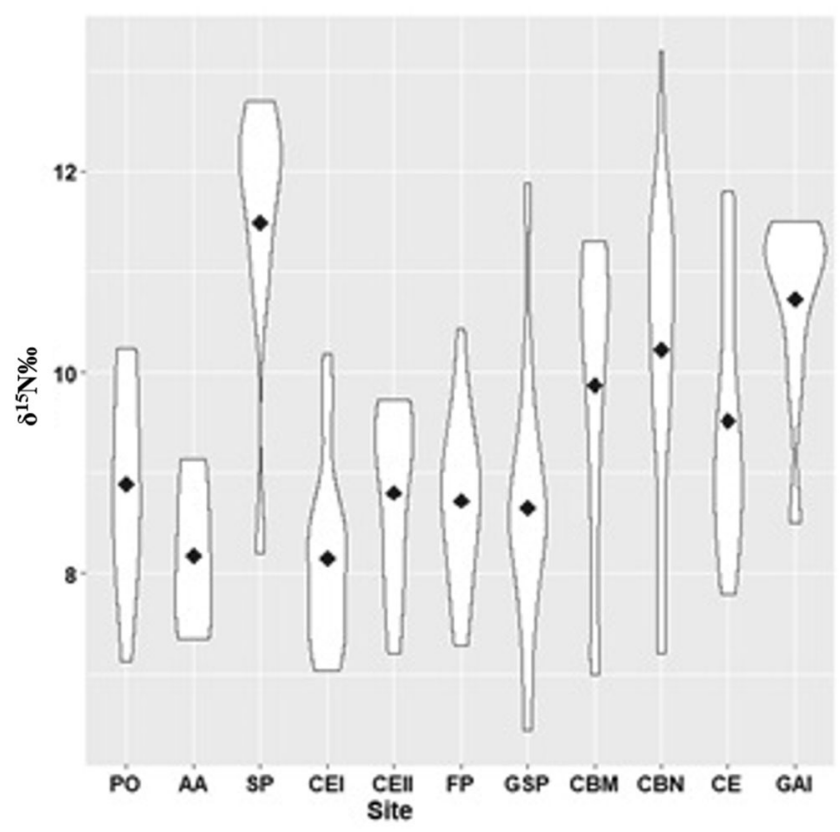

Fig. 6 Violin plots for the $\delta^{15} \mathrm{~N}$ values of each site (PO, Piazzale Ostiense; AA, Amba Aradam; SP, San Pancrazio; CEI, Celio I; CEII, Celio II; FP, Foro della Pace; GSP, Gabii San Primitivo; CBM, Casal Bertone Mausoleum; CBN, Casal Bertone Necropolis; CE, Castellaccio Europarco; GAI, Imperial Gabii) 
scattered around the average values of each community in the imperial plots than in the medieval ones, where only a few isotopic outliers could be identified (Fig. 6). These data suggest a significant variability in dietary protein sources in Imperial Rome (first-third centuries CE). This variability decreased in the post-imperial period. From this viewpoint, the main factor accounting for the food transition in ancient Rome could be the trade system crisis, which narrowed the food sources available to Medieval Romans. Commerce was a leading sector of the economy in the Imperial Age (first-third centuries $\mathrm{CE}$ ) and numerous routes to Rome led to a great heterogeneity of available products, such as grains, meats, and spices, from both within and outside the Empire (McLaughlin 2010).

The Empire's crisis caused Rome to lose its leading economic role and the most important imperial trade routes were disrupted, resulting in a crisis for the indoor food markets of the Imperial Age (Holleran 2012). Nevertheless, it should be noted that the dietary shift from the Imperial Age (first-third centuries CE) to the Early Middle Ages (sixth-ninth centuries $\mathrm{CE}$ ) in Rome was different from the dietary transition experienced in other European areas, such as Spain and Croatia (Lightfoot et al. 2012; López-Costas and Müldner 2016), underlining that the lifestyle in the heart of the Empire was different from that in faraway areas.

\section{Conclusions}

This study is the first extensive survey of the food habits of medieval Rome's ancient inhabitants.

Despite literary sources and archeological reports providing a comprehensive picture of medieval Roman's dietary habits (Montanari 1988, 2012; Pearson 1997; Minniti 2000; Facchin et al. 2018), very few molecular information is currently available for supporting the historical reconstruction (Salamon et al. 2008; Pescucci et al. 2013).

In this study, literature data provided a context and framework to properly understand the isotopic data generated from the analysis of 110 individuals living in Rome and the ancient city of Gabii. Overall, the combination of historical, archeological, and dietary data contributed to deepen the knowledge about some aspects of the lifestyle in Rome after the fall of the Western Roman Empire (476 CE).

The outcomes obtained from the isotopic examination revealed medieval dietary behaviors resulted directly from the events following the Roman Empire's collapse. The deep social, demographic, and economic crisis of the Roman world after the third century CE had an important impact on the lifestyle of Roman people (Santangeli Valenzani 2004). The Gothic wars (461-476 CE) induced famine and the spread of diseases, causing the city to be largely abandoned as the population fled to outlying villages (Montanari 1984). All of these factors could have resulted in a change of dietary habits: a more self-sufficient economy was established, with a significant decrease in the consumption of high-protein foods, both from the terrestrial and aquatic environment, and an increase in consuming $\mathrm{C}_{3}$ plant resources.

The isotopic evaluation detected a clear diachronic dietary transition in ancient Rome, demonstrating how the complex historical period following the downfall of the Empire influenced Roman society's lifestyle. In particular, the economic crisis, especially regarding the trade system, must have played a pivotal role in modifying Roman dietary habits, leading to a drop in protein-rich food consumption and dietary variability. This dietary transition is particularly evident comparing the dietary information from the ancient of Gabii, where Imperial isotopic data are also available (Killgrove and Tykot 2017). Furthermore, the data from the sixteenth century CE provided by Salamon et al. (2008) revealed as the Roman diet changed again in the Late Middle Ages, underlying as diet is one of the most retained markers able to identify the cultural identity of an ancient population since it is influenced by cultural, environmental, and historical constraints.

The dietary transition in the heart of the Empire was also revealed to differ from that in other areas of Europe, which implemented different strategies in facing the Roman Empire's collapse (Fuller et al. 2010; Lightfoot et al. 2012; López-Costas and Müldner 2016). Overall, the food system adopted during the Early Middle Ages was not the same throughout Europe, indicating the lack of a large-scale organized system. Trade was less supported, and agriculture became subsistence based, with the type of grain cultivated depending on the geographical and climatic environment, rather than chosen by individual preference.

Acknowledgments The authors are grateful to Andy Bolduc and Martin Bennett for their assistance with the English revision of the manuscript. We are grateful to the anonymous reviewers for their useful suggestions.

Funding information Open access funding provided by Università degli Studi di Roma Tor Vergata within the CRUI-CARE Agreement. This research was supported by the Italian Ministry of Education, Universities and Research (MIUR) through PRIN 2015 (Diseases, health and lifestyles in Rome: from the Empire to the Early Middle Age. Grant ID Prot. 2015PJ7H3K) allotted to V.G., R.S.V., and C.M-L.

\section{Compliance with ethical standards}

Conflict of interest The authors declare that they have no conflicts of interest.

Open Access This article is licensed under a Creative Commons Attribution 4.0 International License, which permits use, sharing, adaptation, distribution and reproduction in any medium or format, as long as you give appropriate credit to the original author(s) and the source, provide a link to the Creative Commons licence, and indicate if changes were made. The images or other third party material in this article are included in the article's Creative Commons licence, unless indicated otherwise in a credit line to the material. If material is not included in the 
article's Creative Commons licence and your intended use is not permitted by statutory regulation or exceeds the permitted use, you will need to obtain permission directly from the copyright holder. To view a copy of this licence, visit http://creativecommons.org/licenses/by/4.0/.

\section{References}

Adamson MW (2004) Food in Medieval Times. Greenwood press, Westport CT

Ahuja JKC, Haytowitz DB, Roseland JM, Wasswa-Kintu S, Showell B, Nickle M, Somanchi M, Khan M, Exler J, Williams JR, Nguyen QA, Pehrsson PR (2017) USDA National Nutrient Database for standard reference dataset for what we eat in America, NHANES (Survey-SR). USDA Agric Res Serv. https://doi.org/10.15482/ USDA.ADC/1409053

Ambrose SH (1993) Isotopic analysis of paleodiets: methodological and interpretative considerations. In: Sandford K (ed) Investigation of ancient human tissue: chemical analyses in anthropology. Gordon and Breach Science Pub, Langhorne, pp 59-130

Ambrose SH, Norr L (1993) Experimental evidence for the relationship of the carbon isotope ratios of whole diet and dietary protein to those of bone collagen and carbonate. In: Lambert JB, Grupe G (eds) Prehistoric human bone: archaeology at the molecular level. Springer, Heidelberg, pp 1-37

Astill G, Lobb SJ (1991) Excavation of prehistoric, Roman and Saxon deposits at Wraysbury, Berkshire. Archaeol J 146:68-134

Augenti A (2016) Archeologia dell'Italia medievale. Laterza, Roma-Bari

Baldoni M, Nardi A, Müldner G, Lelli R, Gnes M, Ferraresi F, Meloni V, Cerino P, Greco S, Manenti G, Angle M, Rickards O, MartínezLabarga C (2016) Archaeobiological reconstruction of the Italian medieval population of Colonna (8th-10th centuries CE). J Archaeol Sci Rep 10:483-494

Baldoni M, Scorrano G, Gismondi A, D’Agostino A, Alexander M, Gaspari L, Vallelonga F, Canini A, Rickards O, Martinez-Labarga C (2018) Who were the miners of Allumiere? A multidisciplinary approach to reconstruct the osteobiography of an Italian worker community. PLoS One 13(10):e0205362. https://doi.org/10.1371/ journal.pone. 0205362

Baldoni M, Scorrano G, Alexander M, Stasolla FR, Marsella LT, Rickards O, Martínez-Labarga C (2019) The medieval population of Leopoli-Cencelle (Viterbo, Latium): dietary reconstruction through stable isotope analysis from bone proteins. J Archaeol Sci Rep 24:92-101

Beardsworth LJ, Eyre DR, Dickson IR (1990) Changes with age in the urinary excretion of Lysyl- and hydroxylysylpyridinoline, two new markers of bone collagen turnover. J Bone Miner Res 5:671-676

Beaton GH (1992) The Pearl Raymond memorial lecture 1990 - nutrition research in human biology - changing perspectives and interpretations. Am J Hum Biol 4:159-177

Becker JA, Mogetta M, Terrenato N (2009) A new plan for an ancient Italian city: Gabii revealed. Am J Archaeol 113(4):629-642

Brown TA, Nelson DE, Vogel JS, Southon JR (1988) Improved collagen extraction by modified Longin method. Radiocarbon 30:171-177

Buonincontri MP, Pecci A, Di Pasquale G, Ricci P, Lubritto C (2017) Multiproxy approach to the study of Medieval food habits in Tuscany (central Italy). Archaeol Anthropol Sci 9:653-671

Castagnoli GC, Bonino G, Taricco C, Bernascosi SM (2002) Solar radiation variability in the last 1400 years recorded in the carbon isotope ratio of a Mediterranean Sea core. Adv Space Res 29:1989-1994

Castelletti L, Mottella De Carlo S (2008) La situazione delle ricerche tra archeobotanica e alimentazione in Piemonte nel quadro delle attività di laboratorio di archeobiologia di Como. In: Mercuri AM, Baroni
R, Mariotti L (eds) Archeobotanica e alimentazione. Firenze 18 dicembre 2006, pp 275-286

Chisholm BS, Nelson DE, Schwarcz HP (1982) Stable-carbon isotope ratios as a measure of marine versus terrestrial protein in ancient diets. Science 286:1131-1132

Ciaffi R, Lelli R, Müldner G, Stantcheva K, Fischetti AL, Ghini G, Craig OE, Milano F, Rickards O, Arcudi G, Martínez-Labarga C (2015) Palaeobiology of the medieval population of Albano (Rome, Italy): a combined morphological and biomolecular approach. Int $\mathrm{J}$ Osteoarchaeol 25:477-488

Clavel B (2001) L'animal dans l'alimentation me'die'vale et moderne en France du Nord (XIIIeeXVIIe sie'cles). Revue arche'ologique de Picardie, Nume'ro spe'cial. Socie'te' des antiquite's historiques de Picardie [Amiens]

Coplen TB (1996) New guidelines for reporting stable hydrogen, carbon, and oxygen isotope-ratio data. Geochim Cosmochim Acta 60:33593360

Cortonesi A, Pasquali G, Piccinini G (2002) Uomini e campagne nell'Italia medievale. Laterza, Roma-Bari

Craig OE, Biazzo M, O'Connell TC, Garnsey P, Martinez-Labarga C, Lelli R, Salvadei L, Tartaglia G, Nava A, Renò L, Fiammenghi A, Rickards O, Bondioli L (2009) Stable isotopic evidence for diet at the Imperial Roman coastal site of Velia (1st and 2nd centuries AD) in Southern Italy. Am J Phys Anthropol 139:572-583

De Angelis F, Scorrano G, Martínez-Labarga C, Giustini F, Brilli M, Pacciani E, Silvestrini M, Calattini M, Volante N, Martini F, Sarti L, Rickards O (2019) Eneolithic subsistence economy in Central Italy: first dietary reconstructions through stable isotopes. Archaeol Anthropol Sci 11:1-16

De Niro MJ (1985) Post-mortem preservation and alteration of in vivo bone collagen isotope ratios in relation to palaeodietary reconstruction. Nature 317:806-809

Delogu P (2000) Solium imperii - urbs ecclesiae. Roma fra la tarda antichità e l'alto medioevo. In Ripoll G, Gurt JM (eds), Sedes regiae (ann. 400-800), Barcelona, pp 83-108

Dyer C (1993) Everyday life in medieval England. Hambledon Press, London

Ervynck A, Van Neer W, Hüster-Plogmann H, Schibler J (2003) Beyond affluence: the zooarchaeology of luxury. World Archaeol 34:428 441

Facchin G, Rea R, Santangeli Valenzani R (2018) Anfiteatro Flavio. Trasformazioni e riusi. Ediz. Illustrata. Mondadori Electa, Florence

Fernandes R, Nadeau MJ, Grootes PM (2012) Macronutrient-based model for dietary carbon routing in bone collagen and bioapatite. Archaeol Anthropol Sci 4(4):291-301

Fernandes R, Millard AR, Brabec M, Nadeau MJ, Grootes P (2014) Food reconstruction using isotopic transferred signals (FRUITS): a Bayesian model for diet reconstruction. PLoS One 9(2):e87436

Fogel ML, Tuross N, Owsley DW (1989) Nitrogen isotope tracers of human lactation in modern and archeological populations. Annual Report of the Director of the Geophysical Laboratory, Carnegie Instn Washington, 1988-1989. Washington, DC: Geophysical Laboratory

Fontanals-Coll M, Eulàlia Subirà M, Díaz-Zorita Bonilla M, Gibaja JF (2017) First insight into the Neolithic subsistence economy in the north-East Iberian Peninsula: paleodietary reconstruction through stable isotopes. Am J Phys Anthropol 62:36-50

Fraser RA, Bogaard A, Schäfer M, Arbogast R, Heaton THE (2013) Integrating botanical faunal and human stable carbon and nitrogen isotope values to reconstruct land use and palaeodiet at LBK Vaihingen an der Enz Baden-Wurttemberg. World Archaeol 45: 492-517

Fuller BT, Fuller JL, Harris DA, Hedges REM (2006) Detection of breastfeeding and weaning in modern human infants with carbon and nitrogen stable isotope ratios. Am J Phys Anthropol 129:279_ 283 
Fuller BT, Márquez-Grant N, Richards MP (2010) Investigation of diachronic dietary patterns on the islands of Ibiza and Formentera, Spain: evidence from carbon and nitrogen stable isotope ratio analysis. Am J Phys Anthropol 143:512-522

Gannes LZ, O'Brien DM, del Rio CM (1997) Stable isotopes in animal ecology: assumptions, caveats, and a call for more laboratory experiments. Ecology 78:1271-1276

García-Collado MI, Ricci P, Ramos RC, Altieri S, Lubritto C, Quirós Castillo JA (2019) Palaeodietary reconstruction as an alternative approach to poorly preserved early medieval human bone assemblages: the case of Boadilla (Toledo, Spain). Archaeol Anthropol Sci 11:3765-3782

Garnsey (1999) Food and society in classical antiquity. Cambridge University Press, Cambridge

GBrescia MA, Di Martino G, Fares C, Di Fonzo N, Platani C, Ghelli S, Reniero F, Sacco A (2002) Characterization of Italian durum wheat semolina by means of chemical analytical and spectroscopic determinations. Cereal Chem 79:238-242

Gismondi A, Baldoni M, Gnes M, Scorrano G, D’Agostino A, Di Marco G, Calabria G, Petrucci M, Müldner G, Von Tersch M, Nardi A, Enei F, Canini A, Rickards O, Alexander M, Martínez-Labarga C (2020) A multidisciplinary approach for investigating dietary and medicinal habits of the Medieval population of Santa Severa (7th15th centuries, Rome, Italy). PLoS One 15(1):e0227433

Graeber (2011) Debt: the first 5,000 years. Melville House, Brooklyn

Hakenbeck SE, McManus E, Geisler H, Grupe G, O'Connell TC (2010) Diet and mobility in Early Medieval Bavaria: a study of carbon and nitrogen stable isotopes. Am J Phys Anthropol 143:235-249

Hammer Ø, Harper DAT, Ryan PD (2001) PAST: paleontological statistics software package for education and data analysis. Palaeontol Electron 4:9

Heather P (2006) The fall of the Roman empire. A new history. Oxford University Press, Oxford

Hedges REM, Clement JG, Thomas CDL, O'Connell TC (2007) Collagen turnover in the adult femoral mid-shaft: modeled from anthropogenic radiocarbon tracer measurements. Am J Phys Anthropol 133:808-816

Herring DA, Saunders SR, Katzenberg MA (1998) Investigating the weaning process in past populations. Am J Phys Anthropol 105: 425-439

Hobson KA, Clark RG (1992) Assessing avian diets using stable isotopes II: factors influencing diet-tissue fractionation. Condor 94:189-197

Hoffmann RC (1975) Medieval origins of the common fields. In: Parker WN, Jones EL (eds) European peasants and their markets. Princeton University Press, Princeton, p 38

Hoffmann RC (2015) Salmo salar in late medieval Scotland: competition and conservation for a riverine resource. Aquat Sci 77:355-366

Holleran C (2012) Shopping in ancient Rome: the retail trade in the late republic and the principate. Oxford University Press, Oxford

Hopkins K (2009) The political economy of the Roman empire. In: Morris I, Scheidel W (eds) The dynamics of ancient empires: state power from Assyria to Byzantium. Oxford University Press, Oxford, pp 178-204

Iacumin P, Galli E, Cavalli F, Cecere L (2014) C4-consumers in southern Europe: the case of Friuli V.G. (NE-Italy) during early and central Middle Ages. Am J Phys Anthropol 154:561-574

Itahashi Y, Tsuneki A, Dougherty SP, Chikaraishi Y, Ohkouchi N, Yoneda M (2018) Dining together: reconstruction of Neolithic food consumption based on the $\delta^{15} \mathrm{~N}$ values for individual amino acids at Tell el-Kerkh, northern Levant. J Archaeol Sci Rep 17:775-784

Katzenberg M (2008) Stable isotope analysis: a tool for studying past diet, demography, and life history. Wiley-Liss, New York

Katzenberg MA, Lovell NC (1999) Stable isotope variation in pathological bone. Int J Osteoarchaeol 9:316-324
Killgrove K, Tykot RH (2013) Food for Rome: a stable isotope investigation of diet in the Imperial period ( 1 st-3rd centuries AD). J Anthropol Archaeol 32:28-38

Killgrove K, Tykot RH (2017) Diet and collapse: a stable isotope study of Imperial-era Gabii (1st- $3^{\text {rd }}$ centuries AD). J Archaeol Sci Rep 19: 1041-1049

Kulikowski M (2008) Rome's gothic wars: from the third century to Alaric. Cambridge University, Press Cambridge

Lanconelli A (1990) I lavori alla peschiera del Marta. Contributo alla storia della pesca nel Lazio bassomedievale, Scritti in memoria di Giuseppe Marchetti Longhi. Istituto di Storia e di Arte del Lazio meridionale, Anagni, pp 233-249

Lelli R, Allen R, Biondi G, Calattini M, Conati Barbaro C, Gorgoglione MA, Manfredini A, Martínez-Labarga C, Radina F, Silvestrini M, Tozzi C, Rickards O, Craig OE (2012) Examining dietary variability of the earliest farmers of south-eastern Italy. Am J Phys Anthropol 149:380-390

Lightfoot E, Slaus M, O’Connell TC (2012) Changing cultures, changing cuisines: cultural transitions and dietary change in iron age, roman, and early medieval Croatia. Am J Phys Anthropol 148:543-556

López-Costas O, Müldner G (2016) Fringes of the empire: diet and cultural change at the Roman to post-Roman transition in NW Iberia. Am J Phys Anthropol 161(1):141-154

Lubell D, Jackes M, Schwarcz H, Knyf M, Meiklejohn C (1994) The Mesolithic-Neolithic transition in Portugal: isotopic and dental evidence of diet. J Archaeol Sci 21:201-216

Mariotti A (1983) Atmospheric nitrogen is a realiable standard for natural $15 \mathrm{~N}$ abundance measurements. Nature 303:685-687

McCormick M (2001) Origins of the European economy. Communications and commerce. A.D. 300-900. Cambridge University press, Cambridge

McDermott F, Mattey DP, Hawkesworth C (2005) Centennial-scale Holocene climate variability revealed by a high-resolution speleothem $\delta^{18}$ O record from SW Ireland. Science 294:1328-1331

McElroy A, Townsend PK (1989) Medical anthropology in ecological perspective. Westview Press, Boulder

McLaughlin R (2010) Rome and the distant east: trade routes to the ancient lands of Arabia, India, and China. Continuum, London

Mekota AM, Grupe G, Ufer S, Cuntz U (2006) Serial analysis of stable nitrogen and carbon isotopes in hair: monitoring starvation and recovery phases of patients suffering from anorexia nervosa. Rapid Commun Mass Spectrom 20:1604-1610

Minniti C (2000) L'approvvigionamento alimentare a Roma nel Medioevo: analisi dei resti faunistici provenienti dalle aree di scavo della Crypta Balbi e di Santa Cecilia In: Atti $3^{\circ}$ Convegno Nazionale di Archeozoologia (Siracusa, 2000), pp 469-492

Mion L, Herrscher E, André G, Hernandez J, Donat R, Fabre M, Forest V, Salazar-Garcì DC (2019) The influence of religious identity and socio-economic status on diet over time, an example from medieval France. Archaeol Anthropol Sci 11:3309-3327

Mogetta M, Becker JA (2014) Archaeological research at Gabii, Italy: the Gabii project excavations, 2009-2011. Am J Archaeol 118:171-188

Montanari M (1979) L'alimentazione contadina nell'alto Medioevo. Liguori Editore, Napoli

Montanari M (1981) Storia, alimentazione e storia dell'alimentazione: le fonti scritte altomedievali. Archeol Med 8:25-37

Montanari M (1984) Campagne Medievali. Einaudi, Torino

Montanari M (1988) Alimentazione e cultura nel Medioevo. Laterza, Roma-Bari

Montanari M (2012) Gusti nel Medioevo. Laterza, Roma-Bari

Morrison DJ, Dodson B, Slater C, Preston T $(2000){ }^{13} \mathrm{C}$ natural abundance in the British diet: implications for ${ }^{13} \mathrm{C}$ breathe tests. Rapid Commun Mass Spectrom 14:1312-1324

Nada Patrone AMN (1981) Il cibo del ricco e il cibo del povero: contributo alla storia qualitativa dell'alimentazione; l'area 
pedemontana negli ultimi secoli del Medio Evo. Centro Studi Piemontesi, Torino

O'Connell TC, Kneale CJ, Tasevska N, Kuhnle GG (2012) The diet-body offset in human nitrogen isotopic values: a controlled dietary study. Am J Phys Anthropol 149(3):426-434

Olsen KC, White CD, Longstaffe FJ, von Heyking K, McGlynn G, Grupe $\mathrm{G}$, Rühli FJ (2014) Intraskeletal isotopic compositions $\left(\delta^{13} \mathrm{C}\right.$ and $\delta^{15} \mathrm{~N}$ ) of bone collagen: nonpathological and pathological variation. Am J Phys Anthropol 153:598-604

Pearson KL (1997) Nutrition and the early-medieval diet. Speculum 72: $1-32$

Pescucci L, Battistini A, De Angelis F, Catalano P (2013) Vivere al centro di Roma nell'VIII secolo d.C. Indicazioni antropologiche. Bollettino di Archeologia On-Line 4:113-138

Pestle WJ, Laffoon J (2018) Quantitative paleodietary reconstruction with complex foodwebs: an isotopic case study from the Caribbean. J Archaeol Sci Rep 17:393-403

Pounds NJG (2014) An economic history of medieval Europe. Taylor\&Francis, London

Prowse T, Schwarcz HP, Saunders S, Macchiarelli R, Bondioli L (2004) Isotopic paleodiet studies of skeletons from the Imperial Roman-age cemetery of Isola Sacra, Rome, Italy. J Archaeol Sci 31:259-272

Prowse T, Schwartz HP, Saunders SR, Macchiarelli R, Bondioli L (2005) Isotopic evidence for age-related variation in diet from Isola sacra, Italy. Am J Phys Anthropol 128(1):2-13

Prowse TL, Saunders SR, Schwarcz HP, Garnsey P, Macchiarelli R, Bondioli L (2008) Isotopic and dental evidence for infant and young child feeding practices in an imperial Roman skeletal sample. Am J Phys Anthropol 137(3):294-308

Quilici L (1977) La Via Prenestina, i suoi monumenti, i suoi paesaggi. Bulzoni Editore, Rome

R Core Team (2014) R: a language and environment for statistical computing. R Foundation for Statistical Computing, Vienna, Austria. URL http://www.R-project.org/

Rawson B (2003) Children and childhood in Roman Italy. Oxford University Press, Oxford

Reitsema LJ, Vercellotti G (2012) Stable isotope evidence for sex- and status-based variations in diet and life history at medieval TrinoVercellese, Italy. Am J Phys Anthropol 148:589-600

Ricci P, Mongelli V, Vitiello A, Campana S, Sirignano C, Rubino M, Fornaciari G, Lubritto C (2012) The priviledged burial of the PavaPieve (Siena, 8th century AD). Rapid Commun Mass Spectrom 26:2393-2398

Salamon M, Coppa A, McCormick M, Rubini M, Vargiu R, Tuross N (2008) The consilience of historical and isotopic approaches in reconstructing the medieval Mediterranean diet. J Archaeol Sci 35: $1667-1672$

Salesse K, Fernandes R, de Rochefort X, Brůžek J, Castex D, Dufour É (2018) IsoArcH.eu: an open-access and collaborative isotope database for bioarcheological samples from Graeco-Roman world and its margins. J Archaeol Sci Rep 19:1050-1055

Saltini A (2010) I semi della civiltà. Frumento, riso e mais nella storia delle società umane. Nuova Terra Antica, Bologna

Santangel Valenzani R (2011) Edilizia residenziale in Italia nell'alto Medioevo. Carocci Editore, Roma
Santangeli Valenzani R (2004) Abitare a Roma nell'alto Medioevo. In: Paroli L, Vendittelli L (eds) Roma dall'antichità al Medioevo. II. Contesti tardoantichi e medievali Electa, Milano, pp 41-59

Saunders SR, Barrans L (1999) Human growth in the past. Cambridge University Press, Cambridge

Schwarcz HP, Schoeninger MJ (1991) Stable isotope analyses in human nutritional ecology. Am J Phys Anthropol 34:283-321

Scorrano G (2018) The stable isotope method in human paleopathology and nutritional stress analysis. Archaeol Anthropol Open Access 1: $1-3$

Scorrano G, Brilli M, Martínez-Labarga C, Giustini F, Pacciani E, Chilleri F, Scaldaferri F, Gasbarrini A, Gasbarrini G, Rickards O (2014) Palaeodiet reconstruction in a woman with probable celiac disease: a stable isotope analysis of bone remains from the archaeological site of Cosa (Italy). Am J Phys Anthropol 154:349-356

Spufford P (2003) Power and profit: the merchant in Medieval Europe. Thames and Hudson, New York

Tieszen LL (1991) Natural variations in the carbon isotope values of plants: implications for archaeology, ecology, and paleoecology. $\mathrm{J}$ Archaeol Sci 18(3):227-248

Tieszen LL, Fagre T (1993) Effect of diet quality and composition on the isotopic composition of respiratory $\mathrm{CO} 2$, bone collagen, bioapatite and soft tissues. In: Lambert JB, Grupe G (eds) Prehistoric human bone: archaeology at the molecular level springer, Berlin, Heidelberg

Torino M, Boldsen JL, Tarp P, Rasmussen KL, Skytte L, Nielsen L, Schiavone S, Terrasi F, Passariello I, Ricci P, Lubritto C (2015) Convento di san Francesco a Folloni: the function of a Medieval Franciscan Friary seen through the burials. Herit Sci 3:27

Tykot RH (2004) Stable isotopes and diet: you are what you eat. Società Italiana di Fisica, Bologna

Unkovich MJ, Pate JS, McNeill A, Gibbs J (2001) Stable Isotope Techniques. Kluwer Academic Publishers, Dordrecht

van Klinken GJ (1999) Bone collagen quality indicators for Palaeodietary and radiocarbon measurements. J Archaeol Sci 26:687-695

Van Neer W, Ervynck A (2004) Remains of traded fish in archaeological sites: indicators of status, or bulk food? In: Jones O’Day S, Van Neer W, Ervynck A (eds) Behaviour behind bones: the zooarchaeology of ritual, religion. Status and Identity. Oxbow Books, Oxford, pp 203214

Ward-Perkins B (2005) The fall of Rome and the end of civilization. Oxford University Press, Oxford

Zapelloni Pavia A, Wright P, Jenkins Z, Johnston AC (2017) A thousand years of transformation in the City Center of Gabii: new evidence from the 2016 excavations. In: Areas G and H Presentation Made at the 118th Joint Annual Meeting of the Archaeological Institute

Zug Tucci H (1985) Il mondo medievale dei pesci tra realta' e immaginazione, L'Uomo di fronte al mondo animale nell'alto medioevo. Centro italiano di studi sull'alto medioevo, Spoleto, $\mathrm{pp}$ 291-360

Publisher's note Springer Nature remains neutral with regard to jurisdictional claims in published maps and institutional affiliations. 